\title{
Retrospect on in vitro androgenesis of sorghum (Sorghum bicolor)
}

\author{
Paul Chege ${ }^{1,2}$ (D) | Csaba Lantos ${ }^{2}$ | János Pauk ${ }^{2}$ (I)
}

${ }^{1}$ Doctoral School of Plant Science, Szent István University, Gödöllő, Hungary

${ }^{2}$ Cereal Research Non-profit Ltd., Szeged, Hungary

\section{Correspondence}

János Pauk, Cereal Research Non-profit Ltd., 6726 Szeged, Alsó kikötő sor 9, Hungary.

Email: janos.pauk@gabonakutato.hu

Funding information

Stipendium Hungaricum

Communicated by: Rod Snowdon

\begin{abstract}
Development of sorghum hybrids can immensely benefit from an enhanced anther culture protocol since the resultant doubled haploids would accelerate, as in other major cereal crops, the attainment of homozygosity and fixation of alleles. Production of the hybrids that have got high yielding, stress tolerance and other traits of industrial significance in a shorter time as compared to the current trend can hence be realized. This review presents the advances that have been made in the development of such a protocol, with closer attention to androgenic induction components of pretreatment, culture media composition and conditions as well as ploidy determination and eventual chromosome doubling. From the findings of this review, it is clear that further work is desired to ensure a protocol, that to a large degree, breaks the genotype dependency trend that has been widely cited to impede the usability of the tested protocols.
\end{abstract}

\section{KEYWORDS}

androgenesis, anther culture, doubled haploids, media, microspore, sorghum

\section{1 | IMPORTANCE OF SORGHUM AND A SHORT HISTORY OF ITS HAPLOID INDUCTION}

\begin{abstract}
Sorghum [Sorghum bicolor (L.) Moench] is one of the most important cereal crops globally and it is ranked fifth in cultivation area after wheat, maize, rice and barley (Srinivasa-Rao et al., 2014). The crop is a staple cereal grain for many of the world's most food insecure people (Tari et al., 2012). According to Srinivasa-Rao et al. (2014) it is the fifth of the most consumed food crops in the world after rice, wheat, maize and potatoes. USDA presented the average global productivity in 2016/2017 as 1.46 t/ha (The Odum Institute, 2017) However, productivity in some countries such as Argentina (4.86 t/ha), the USA (4.89 t/ha) and Egypt (5.36 t/ha) was well above the average. In the Semi-Arid Tropics (SAT) where it is a dietary staple for more than 500 million people, countries in the region including Burkina Faso, Mali, Mozambique, Nigeria, Sudan, and Tanzania to name but a few had meagre yields ( $t / h a)$ of $0.93,1.12,0.60,1.26,0.73$ and 1.00 , respectively, which were below the global average. The low
\end{abstract}

production in some African countries may be attributed to the factors pointed out by Mundia et al. (2019) since the crop is grown for subsistence, where application of agricultural inputs is largely missing owing to affordability, and production is done on marginal lands. Low adoption of hybrids (Mindaye et al., 2016), the inverse of which, as opined by Ringo et al. (2015) could lead to increased yields in this region has also compounded the problem. These are in contrast to the more resource endowed commercial oriented production systems such as in the USA. Additionally, biotic and abiotic stresses are major constraints influencing productivity (Kiranmayee, Kishor, Hash, \& Deshpande, 2015; Mbuvi et al., 2017).

Research aimed at enhancing sorghum resistance to stress factors should be pursued to expand the range of its growth to marginal and barren soils to meet the needs of a growing population, changing diets, and biofuel production (Anami et al., 2015); and assure its availability as food in drought prone environments in the tropics and subtropics (Srinivasa-Rao et al., 2014). It can tolerate low unpredictable rainfall, being a drought resistant crop (Adhikari, Nejadhashemi, \& Woznicki, 2015). Despite remarkable success, sorghum research 
could yield fruits in a shorter period, unlike the current trend, where, according to the data presented by Ndjeunga et al. (2015), there had only been a release of 131 new varieties in the period 1970-2010, in five countries namely Burkina-Faso, Mali, Niger, Nigeria and Senegal. The challenge of the time of genotype development coupled with a more efficient screening of grain and the superior crop trait adoption can be achieved through the biotechnology tool of doubled haploid technology (Barkley \& Chumley, 2012). The benefits of doubled haploid like in other major cereals can immensely impact sorghum hybrid development.

As Wędzony et al. (2009) explains, progress in the doubled haploid technology has been achieved through empirical, time- and cost-consuming testing of protocols, and as a consequence, success over the last few decades has been proportional to the number of laboratories involved. The detailed review by Wędzony et al. (2009) mentions the frequently studied crops whose protocols for the technology have now become routine as barley, triticale, maize, rice and rapeseed. Even with the immense and urgent need to accelerate sorghum hybrid development, it is conspicuously missing out on this list and the cumulative benefits thereof. This is despite its strategic advantage as the grain of the future, due to its low gluten content, high lipid content (Pontieri et al., 2013), in addition to tolerance to climate change related abiotic stresses such as drought.

Some authors point out that the doubled haploid protocols for sorghum remain unavailable or unreproducible (Teingtham, 2017). This is not entirely unexpected as sorghum has been described as one of the most recalcitrant crops for tissue cultures (Zhao et al., 2000). Liang, Gu, Yue, Shi, and Kofoid (1997) opined that factors such as low rate of callus induction and regeneration, high level of polyphenols exudation from somatic tissues and appearance of albino plantlets among regenerants contribute to the dismal success of tissue cultures in sorghum. In somatic tissue culture, Liu et al. (2015) argued that success of sorghum embryogenesis is genotype dependent, although factors such as the ex-plant type and different culture medium modifications have played a role in successful callus formation at various degrees (Teingtham, 2017). Most significantly, in addition to their findings that explant type plays a great role in suppressing polyphenols production and contributing to increased regeneration rates, Liu et al. (2015) reported a drastic reduction in polyphenols production after their induction medium modification with amino acids L- proline and L- asparagine, together with $\mathrm{KH}_{2} \mathrm{PO}_{4}$ and $\mathrm{CuSO}_{4} \cdot 5 \mathrm{H}_{2} \mathrm{O}$ to MS (Murashige \& Skoog, 1962) medium. Further to this work, Chege, Palágyi, Lantos, Kiss, and Pauk (2020) reported that the use of half strength MS medium together with the supplements used by Liu et al. (2015) contributed to attainment of quality callus i.e. $60 \%$ yellow calli with $25 \%$ of them being friable. A doubled haploid development protocol may, however, not benefit from all the gains made in somatic embryogenesis, especially during callus induction, owing to the difference in the explant types involved.

Notable progress has been realized in sorghum doubled haploid production following recent findings in the work of Hussain and Franks (2019) where they report sorghum cultivars SMHIO1 and SMHIO2 as putative haploid inducer lines, although their success rates are very low (1\%-2\%). A patent has been sought for a genetic modification of an endogenous gene encoding patatin phospholipase therefore conferring haploid inducer ability or enhancing the induction performance of sorghum plants (https://patentimages.stora ge.googleapis.com/64/fd/ef/5b5c09747d87c2/EP3366778A1.pdf). These two haploid inducer development methods may be faced with a common problem-early desiccation of embryos from mutants and wide hybridization-as described by Rizal et al. (2014). A method for speed breeding developed by Rizal et al. (2014) in which by splitting a panicle on a single culm, both selfed and crossed progenies were obtained and through embryo rescue the breeding cycle was reduced from 17 to 11 weeks, is a step forward in addressing the mentioned challenges. Some of the other speed breeding techniques described by Hickey et al. (2019) may be explored, to augment, complement or wholly replace the need for doubled haploid technology in future. In this review however, the aim is to present the progress that has been attained in the androgenesis components of pre-treatment, induction and regeneration media composition, ploidy level determination, chromosome duplication in comparison to that in other major cereal crops such as maize, wheat, triticale and rice. As already mentioned, and as argued by Wędzony et al. (2009), success may only be realized by cumulative gains of repeat testing protocols.

\section{2 | GENERAL DESCRIPTION OF DOUBLED HAPLOID TECHNOLOGY}

Doubled haploid lines in sorghum can reduce the time to homozygosity in breeding by accelerating efficacy in selection and eliminating the need for prolonged breeding cycles (Chang \& Coe, 2009; Wędzony et al., 2009). The technology's development has involved many researchers over a long period as explained by Wędzony et al. (2009). It requires acquisition of haploids firstly, currently achieved through In vitro androgenesis and gynogenesis sporophytic development induction, wide hybridization and sometimes obtained spontaneously although at a very low frequency in almost every plant species (Hussain \& Franks, 2019).

Androgenesis can be achieved through anther culture or by isolated microspore culture depending on the method followed, with protocols now existing for more than 200 species (Bhojwani \& Dantu, 2013; Wędzony et al., 2009). The process leads to the development of embryos rather than pollen grains from male gametes thus requiring a complete reprogramming of the developmental plan. The induction sees to the shift from maturation of the highly specialized pollen cells to sporophytic development and is only possible, as Touraev et al. (2001) opines at very early developmental stages when the gametic cells appear to be totipotent. The technology draws from the fact that in certain conditions, the microspores which are the first generation of male gametic cells and that have a haploid chromosome complement are amenable to androgenic induction in many species, their production in plant anthers in large numbers providing an advantage as they are relatively easy to access and manipulate (Touraev et al., 2001; Wędzony et al., 2009). These 
conditions include but are not limited to anther, inflorescence and or donor tiller pre-temperature shock; starvation; and or other stress treatment (Touraev et al., 1996; Žárský et al., 1992, 1995); media composition; and growth regulators (Wędzony et al., 2009).

In gynogenesis, reprogramming is not necessary as the embryogenic pathway just needs to be switched on in the female gamete without proper fertilization (Portemer et al., 2015). Wędzony et al. (2009) argues that compared to androgenesis, gynogenesis is not effective because of the far fewer eggs produced by plantlets than pollen grains. Nevertheless, haploids induced from unfertilized ovule and ovary cultures have been reported for many plant species such as Beta vulgaris L., Allium cepa L. and others that are recalcitrant to androgenesis (Keller \& Korzun, 1996; Teingtham, 2017).

Wide hybridization, a technique where a genetically relatively distant male partner or pollinator possessing special genetic properties such as haploid inducing genes is crossed with a desirable female has been reported to be effective in haploid production (Hussain \& Franks, 2019). On fertilization, the male genetic material gets eliminated from cells of the developing embryo at early stages of its growth (Wędzony et al., 2009). According to Hussain and Franks (2019), when an inducer line is used to pollinate a diploid plant, most of the embryos produced are regular hybrid embryos, but a smaller proportion of haploid maternal embryos are produced.

\section{3 | ANDROGENESIS IN SORGHUM}

Research geared towards the optimization of a doubled haploid development protocol for sorghum [Sorghum bicolor (L.) Moench] by Rose et al. (1986) represents one of the earliest works in the crop. They reported the importance of incubation temperature in anther response rate and $33^{\circ} \mathrm{C}$ as the optimum, although they regenerated only four albino plantlets of unknown ploidy from more than 1,000 anther-origin calli. In what was a significant improvement from these findings, Wen et al. (1991) regenerated 29 plantlets from one cultivar 'Xin White', on medium MS-d-4 (modified Murashige and Skoog, [1962] medium) out of an anther culture of six sorghum cultivars on three induction media. While Wen et al. (1991) concluded that they may have developed sorghum haploids owing to the resultant albino plantlets among the regenerants, they identified diploid number of chromosomes in the regenerants, an indicator that the induced calli may have been from somatic tissues rather than from microspores. Like many other works involving sorghum tissue culture, the calli induction frequencies in this work being $4.3 \%, 3.2 \%$ and $0.1 \%$ for media C17-2, MS-t-z-2 and 85D3-2, respectively were low, and genotype dependence was observed (Wen et al., 1991). In a later experiment, Kumaravadivel and Sree Rangasamy (1994) successfully induced calli at the rate of 40 calli per every 100 anthers in a culture of a hybrid line of sorghum, CSH5 (2077A $\times$ C83541). The anthers of the hybrid line had been cultured on $\mathrm{N}_{6}$ medium (Chu, Wang, Sun, Chen, \& Yin, 1975) supplemented with 3.0\% sucrose. $2.0 \mathrm{mg} / \mathrm{L}$ 2,4-Dichlorophenoxyacetic Acid (2,4-D), 0.8\% agar incubated at $30^{\circ} \mathrm{C}$. The experiment reported a regeneration frequency of $7.6 \%$ on modified MS medium supplemented with $3.0 \%$ sucrose, $2.0 \mathrm{mg} / \mathrm{L}$ Benzyl Amino Purine (BAP) combined with $0.3 \mathrm{mg} / 1$ Indole-Acetic Acid (IAA) and for gelatinizing the medium, 0.8\% agar was used (Kumaravadivel \& Sree Rangasamy, 1994).

\section{4 | PRE-TREATMENT OF DONOR TILLERS}

As earlier mentioned, for androgenic induction, certain conditions (abiotic stresses) must be met for the male gametes to be reprogrammed to sporophytic development. While Wędzony et al. (2009) argued that the role of abiotic stress factors in androgenic induction are not completely understood, and therefore not perfectly controlled in most experiments, still, they provided case for two distinct functions in their review: synchronization of the developmental process of microspores (Hu \& Kasha, 1999) and determination of the developmental stage of microspores (Binarova, Straatman, Hause, Hause, \& van Lammeren, 1993; Hause, Hause, Pechan, \& van Lammeren, 1993). Some of the stresses as earlier stipulated and as presented by Bhojwani and Dantu, (2013) include: starvation, temperature shock, osmotic stress, colchicine, $n$-butanol treatment and others applied to whole plants in vivo, tillers, buds, or isolated anthers or microspore in vitro.

In their work, Rose et al. (1986), pre-treated sorghum tillers by wrapping them in polythene and aluminium foil and keeping them in darkness for 28,35 or 42 days at $7^{\circ} \mathrm{C} ; 10,14$ or 18 days at $14^{\circ} \mathrm{C} ; 7$, 10 or 13 days at $20^{\circ} \mathrm{C} ; 3,4$ or 5 days at $25^{\circ} \mathrm{C}$; and $1,2,3$ or 4 days at $28^{\circ} \mathrm{C}$. They further included an unpretreated control and distributed tillers sequentially among the treatments with seven repeats over the growing period to avoid the effect of donor plant environment on anther performance in vitro. At the ideal incubation temperature $\left(33^{\circ} \mathrm{C}\right)$, Rose et al. (1986) concluded that long-temperature stress pre-treatments were not advantageous to callus induction. They argued that panicle pre-treatments at $7^{\circ} \mathrm{C}, 14^{\circ} \mathrm{C}, 20^{\circ} \mathrm{C}, 25^{\circ} \mathrm{C}$ and $28^{\circ} \mathrm{C}$ either had no effect or significantly decreased callus yield. The experiment rather, found incubation temperature to have significant effect on yields of microspore-derived callus.

On their part, Wen et al. (1991) did not conduct any pre-treatments other than panicle sterilization in $60 \%$ ethanol, which as Wędzony et al. (2009) argue, could be considered a stress treatment. According to Wen et al. (1991), callus induction was genotype dependent for any given medium and culture conditions. In the work of Kumaravadivel and Sree Rangasamy (1994) a heat shock of $35^{\circ} \mathrm{C}$ for $12 \mathrm{hr}$ followed by an incubation temperature of $25^{\circ} \mathrm{C}$ was included in one of the treatments, however, it did not prove to have any advantage to the eventual number of calli induced. Ideal incubation temperature was argued to be the main causative of callus induction (Kumaravadivel \& Sree Rangasamy, 1994). This argument corroborated that of Rose et al. (1986), although they differed on the ideal incubation temperature as already pointed out earlier on in this paper.

Apart from temperature stress, whose role in influencing microspore transition from gametophytic to sporophytic development was discussed by Touraev et al. (1997), no work on sorghum anther 
culture has been done with other types of pre-treatment. In recent works, it is now quite commonplace to combine a relatively short low or high temperature treatment with osmotic starvation stress or interchange the two (Hoekstra, van Bergen, van Brouwershaven, Schilperoort, \& Wang, 1997; Jacquard, Wojnarowiez, \& Clément, 2003; Kasha et al., 2002; Wędzony et al., 2009), such as a pre-treatment of $14^{\circ} \mathrm{C}$ in a medium containing mannitol, that was done to improve androgenic efficiency in maize (Nageli et al., 1999; Zheng et al., 2003). In a separate experiment, when used together with growth regulators, starvation stress in mannitol gave satisfactory results in callus induction in maize (Liu et al., 2002a, 2002b). Kasha, $\mathrm{Hu}$, Oro, Simion, and Shim (2001) in an experiment on cytology of barley (Hordeum vulgare L.) microspores at uni-nucleate stage during pre-treatment at the early culture stage concluded that spike pre-treatment with $0.3 \mathrm{M}$ mannitol at $4^{\circ} \mathrm{C}$ for 4 days was preferable as it appeared to provide genotype independent induction and suspension of nuclear division as well as regeneration of green plants at a shorter time compared to when the spikes were pre-treated with cold temperature alone, findings that are similar to those of Liu, Zheng, and Konzak (2002), Liu, Zheng, Polle, et al. (2002). Prior to this, Indrianto, Heberle-Bors, and Touraev (1999) had demonstrated that wheat microspore embryogenesis was possible with a combination of high temperature shock in mannitol treatment. Zhao et al. (1996) had demonstrated that colchicine could induce microspore embryogenesis without requiring heat shock (at non-inductive temperature of $25^{\circ} \mathrm{C}$ ) in Brassica napus L. cv. 'Topas'. The above examples go to reiterate that stress is the major trigger in inducing microspore embryogenesis from many monocots and dicots as pointed out by Touraev et al. (1997). Many of the existing protocols utilize one or more of the common stress inducing components: heat shock, cold shock, carbohydrate or nitrogen starvation and colchicine pre-treatment (Indrianto et al., 1999), but rest for the work of Rose et al. (1986), literature for pre-treatment in sorghum anther culture is largely lacking. Rose et al. (1986) opined that inductive benefits of pre-treatment maybe partly offset by the acceleration of production of polyphenols in the anther wall in sorghum. According to them, tissue damage in sorghum tend to stimulate production of polyphenols, also referred to by some authors as lethal browning (Ko, Su, Chen, \& Chao, 2008), therefore causing death to the developing microspores.

\section{5 | CULTURE MEDIA AND CONDITIONS}

Like other androgenic inductions, sorghum anther culture would require a culture medium with an organic nitrogen source, carbohydrates and growth regulator components as stipulated by Wędzony et al. (2009). Unfortunately for the crop, there hasn't been a reproducible culture medium. Rose at al. (1986) reported a total of 1,174 anther-derived calli induced on liquid potato extract (Chuang, Ouyang, Chia, Chou, \& Ching, 1978) with $9 \%$ sucrose (w/v), $0.5 \mathrm{mg} / \mathrm{L}$ kinetin, and different concentrations of 2,4-D incubated in darkness at $33^{\circ} \mathrm{C}$. According to Rose et al. (1986), callus yield and anther response rates were highest at media containing 2-3 mg/L 2,4-D concentrations and that there was a marked difference in phenolics production (media discolouration) between the media that had 2,4-D and those without. On regeneration, this first sorghum anther culture experiment utilized half strength MS medium (Murashige \& Skoog, 1962), modified with a range of auxins and cytokinins at different concentrations. They used kinetin at $0.5 \mathrm{mg} / \mathrm{L}$ which had been reported by Wernicke et al. (1982) to stimulate organ differentiation from leaf cultures of sorghum; and $\alpha$-naphthalene-acetic acid (NAA) at $5 \mathrm{mg} / \mathrm{L}$ which Masteller and Holden (1970) had recommended for sorghum callus differentiation. Rose et al. (1986) additionally used a combination of BAP at $2 \mathrm{mg} / \mathrm{L}$ and IAA at $1 \mathrm{mg} / \mathrm{L}$ as had been used by Huang and Sunderland (1982) for barley anther-derived callus differentiation. The regeneration media used in this experiment also comprised of $2 \%(\mathrm{w} / \mathrm{v})$ sucrose and $0.8 \%(\mathrm{w} / \mathrm{v})$ agar as the gelling agent.

It was reported, that incubation temperature had a significant effect on anther response, with those incubated at $33^{\circ} \mathrm{C}$ in a $10 \mathrm{hr}$-photoperiod giving the highest response as those incubated at $20^{\circ}, 25^{\circ}$ or $30^{\circ} \mathrm{C}$ rapidly turned black and died (Rose et al., 1986). At this temperature, they also reported a reduced discolouration of the medium and anthers. Eventually, four calli were regenerated into albino plantlets on a half strength MS medium containing only $0.1 \mathrm{mg} / \mathrm{L}$ 2,4-D after a 3-stage regeneration process that entailed: first stage- transfer of calli to a regeneration medium containing $2 \mathrm{mg} / \mathrm{L}$ 2,4-D on which individual calli proliferated, lost their original structure and developed basal calli that were in contact with the medium surface (and were yellow, relatively loose and unstructured) while surface cells on the other hand either formed smooth brown gelatinous callus or compact white partially structured calli, which were sub-cultured every 7-10 days failure to which the calli discoloured; and a second stage- where leaf-like structures formed on the semi structured calli from stage one being transferred to a medium containing BAP and $2 \mathrm{mg} / \mathrm{L}$ 2,4-D, which were then transferred to the third stage after 14 days.

In their work, Wen et al. (1991) incubated 21,000 anthers over a period of 18 months on free media (Table. 1) namely MS-t-z-2, C17-2 and $85 \mathrm{D} 3-2$ in darkness at $28 \pm^{\circ} \mathrm{C}$ until calli were formed. Out of the 29 varieties involved in the trial, only six namely: 'Xin White', 'Tx 403-TSB', 'DDY Sooner milo', 'Tx 2779', 'Brawley', and 'Spur Federal' formed calli at different frequencies, with 'Xin White' and 'TX 403-TSB' having significantly higher callus induction frequencies than the other four at $6.7 \%$ and $3.9 \%$ respectively. There were significantly higher callus induction frequency rates on media C17-2 (3.6\%) and MS-t-z-2 (4.1\%) than on medium 85D3-2 (0.1\%). Wen et al. (1991) concluded that addition of myo-inositol in MS-t-z-2 and biotin in C17-2 appeared to be beneficial to callus induction and that compared to NAA, 2,4-D as the auxin provided better results.

The sorghum calli induced in the work of Wen et al. (1991) were regenerated on medium MS-d-4 (MS medium supplemented with $2 \mathrm{mg} / \mathrm{L} \mathrm{IAA}$ and $2.5 \mathrm{mg} / \mathrm{L}$ kinetin). Shoots began forming on the $3 \mathrm{~mm}$ calli that were transferred to the regeneration media two to three weeks later. Wen et al. (1991) observed that shoots formed before 
roots in normal regeneration while calli that formed roots first never developed shoots. They also reported that the more the callus

TABLE 1 Components of the media used by Wen et al. (1991) for sorghum anther culture callus induction

\begin{tabular}{|c|c|c|c|}
\hline \multirow[b]{2}{*}{ Components } & \multicolumn{3}{|c|}{ Media (Mg/L) } \\
\hline & MS-t-z-2 & C17-2 & 85D3-2 \\
\hline $\mathrm{KNO}_{3}$ & 1,900 & 1,400 & 2,830 \\
\hline $\mathrm{KN}_{2} \mathrm{PO}_{4}$ & 170 & 400 & 400 \\
\hline $\mathrm{NH}_{4} \mathrm{NO}_{4}$ & 1,650 & 300 & - \\
\hline$\left(\mathrm{NH}_{4}\right)_{2} \mathrm{SO}_{4}$ & - & - & - \\
\hline $\mathrm{CaCl}_{2} \times 2 \mathrm{H}_{2} \mathrm{O}$ & 440 & 150 & 166 \\
\hline $\mathrm{MgSO}_{4} \times 7 \mathrm{H}_{2} \mathrm{O}$ & 370 & 150 & 185 \\
\hline or $\mathrm{MgSO}_{4}$ & 180 & 73.2 & 90.2 \\
\hline $\mathrm{Na}_{2} \cdot$ EDTA & 37.3 & 37.3 & 37.3 \\
\hline $\mathrm{FeSO}_{4} \times 7 \mathrm{H}_{2} \mathrm{O}$ & 27.8 & 27.8 & 27.8 \\
\hline $\mathrm{MnSO}_{4} \times 4 \mathrm{H}_{2} \mathrm{O}$ & 22.3 & 11.2 & 4.4 \\
\hline (or $\mathrm{MnSO}_{4} \times \mathrm{H}_{2} \mathrm{O}$ ) & 17.1 & 8.6 & 3.4 \\
\hline $\mathrm{ZnSO}_{4} \times 7 \mathrm{H}_{2} \mathrm{O}$ & 8.6 & 8.6 & 1.5 \\
\hline $\mathrm{H}_{3} \mathrm{BO}_{3}$ & 6.2 & 6.2 & 1.6 \\
\hline $\mathrm{KI}$ & 0.83 & 0.83 & 0.8 \\
\hline $\mathrm{CuSO}_{4} \times 5 \mathrm{H}_{2} \mathrm{O}$ & 0.025 & 0.025 & - \\
\hline $\mathrm{CoCl}_{2} \times 6 \mathrm{H}_{2} \mathrm{O}$ & 0.05 & 0.025 & - \\
\hline $\mathrm{NaMoO}_{4} \times 2 \mathrm{H}_{2} \mathrm{O}$ & 0.25 & - & - \\
\hline Glycine & 2 & 2 & 2 \\
\hline Thiamine $\mathrm{HCl}$ & 0.1 & 1 & 1 \\
\hline Pyridoxine $\mathrm{HCl}$ & 0.5 & 0.5 & 0.5 \\
\hline Nicotinic acid & 0.5 & 0.5 & 0.5 \\
\hline Myo-inositol & 100 & - & - \\
\hline Casein hydrolysate & - & - & 500 \\
\hline Biotin & - & 1.5 & - \\
\hline $2,4-D$ & 3 & 2 & - \\
\hline NAA & - & - & 1 \\
\hline Kinetin & 0.3 & 1 & 1.5 \\
\hline Zeatin & 2.2 & - & - \\
\hline Sucrose & 20,000 & 20,000 & 30,000 \\
\hline Difco agar & 5,000 & 7,000 & 5,000 \\
\hline $\mathrm{pH}$ & 5.8 & 5.8 & 5.8 \\
\hline
\end{tabular}

induction time, the less the calli regeneration frequency was, and it led to increased number of albino plantlets or regeneration of only roots in a callus.

The experiment by Kumaravadivel and Sree Rangasamy (1994) involved the culture of anthers of a sorghum hybrid CSH5 (2077A $x$ C83541) on $\mathrm{N}_{6}$ medium (Chu et al., 1975) modified with $2.0 \mathrm{mg} / \mathrm{L}$ 2,4-D, 3.0\% (w/v) sucrose and $0.8 \%(\mathrm{w} / \mathrm{v})$ agar at $\mathrm{pH} 5.8$. In the first part of the trial, the anthers were incubated in the dark at $15^{\circ} \mathrm{C}$, $20^{\circ} \mathrm{C}, 25^{\circ} \mathrm{C}, 30^{\circ} \mathrm{C}$ and $35^{\circ} \mathrm{C}$. A total of one hundred and twenty anthers were cultured in each treatment. The effect of different concentrations of 2,4-D at $0.5,1.0,1.5,2.0$ and $2.5 \mathrm{mg} / \mathrm{L}$ in the induction media were tested in the second part of the experiment where the same number of anthers per treatment were incubated in the dark, at $30^{\circ} \mathrm{C}$ and $85 \%$ relative humidity in media with the same components as in part one, but with the different 2,4-D concentrations (Kumaravadivel \& Sree Rangasamy, 1994). In the first part, $30^{\circ} \mathrm{C}$ was reported to have the highest callus induction frequency at $40 \%$ as shown in Table 2.

In the second part of the experiment, 2,4-D at $2 \mathrm{mg} / \mathrm{L}$ was shown to be the most effective in callus induction (Figure 1). It was reported that anthers turned brown 7-10 days after incubation, but white to yellow compact and nodular calli began to grow by the 15 th day of subculture and proliferated on culture for 25-30 days (Kumaravadivel \& Sree Rangasamy, 1994).

Kumaravadivel and Sree Rangasamy (1994) used MS medium modified with B5 vitamins, FeEDTA in double quantity with concentrations of BAP at $1.5,2.0$ and $2.5 \mathrm{mg} / \mathrm{L}$ and IAA at $0.3 \mathrm{mg} / \mathrm{L}$ to determine the optimum concentrations of BAP and IAA necessary for sorghum plantlets regeneration. The embryogenic calli were transferred to the media and incubated at $25 \pm 2^{\circ} \mathrm{C}$ under a 16-hr photoperiod. They reported that on the regeneration media, calli formed clusters of embryoids and contrary to the findings of Wen et al. (1991), roots and shoots developed simultaneously. Regeneration media comprising of $2.0 \mathrm{mg} / \mathrm{L}$ BAP and 0.3 IAA gave the highest calli yield. A total of 1,417 plants were regenerated, whereby 764 were green and 653 were albinos (Kumaravadivel \& Sree Rangasamy, 1994).

In addition, to these three studies, Can, Nakamura, Haryanto, and Yoshida (1998) in their work induced sorghum calli at a mean frequency of $5.1 \%$ from six cultivars. MS medium containing $2.0 \mathrm{mg} / \mathrm{L}$ kinetin, $1.0 \mathrm{mg} / \mathrm{L}$ IAA and $2.5 \mathrm{mg} / \mathrm{L} \mathrm{2,4-D}$ produced the highest callus induction frequency at $6.4 \%$ with the field grown anthers and
TABLE 2 Effect of incubation temperature on callus induction on day 25 as reported by Kumaravadivel and Sree Rangasamy (1994)

\begin{tabular}{llllll}
\multicolumn{5}{l}{ Incubation temperature $\left({ }^{\circ} \mathrm{C}\right)$} & \\
\hline & 15 & 20 & 25 & 30 & $35^{\mathrm{a}}$ \\
\hline $\begin{array}{c}\text { No. of anthers } \\
\text { with calli (\%) }\end{array}$ & $10.1 \pm 0.8$ & $16.4 \pm 2.2$ & $23.7 \pm 1.5$ & $27.6 \pm 2.1$ & $20.5 \pm 3.0$ \\
$\begin{array}{c}\text { No. of calli/100 } \\
\text { anthers }\end{array}$ & $12.3 \pm 1.0$ & $20.0 \pm 0.7$ & $27.1 \pm 3.0$ & $39.9 \pm 1.0$ & $23.0 \pm 2.1$ \\
\hline
\end{tabular}

${ }^{\mathrm{a}} 35^{\circ} \mathrm{C}$ for $12 \mathrm{hr}$ followed by incubation at $25^{\circ} \mathrm{C}$. 


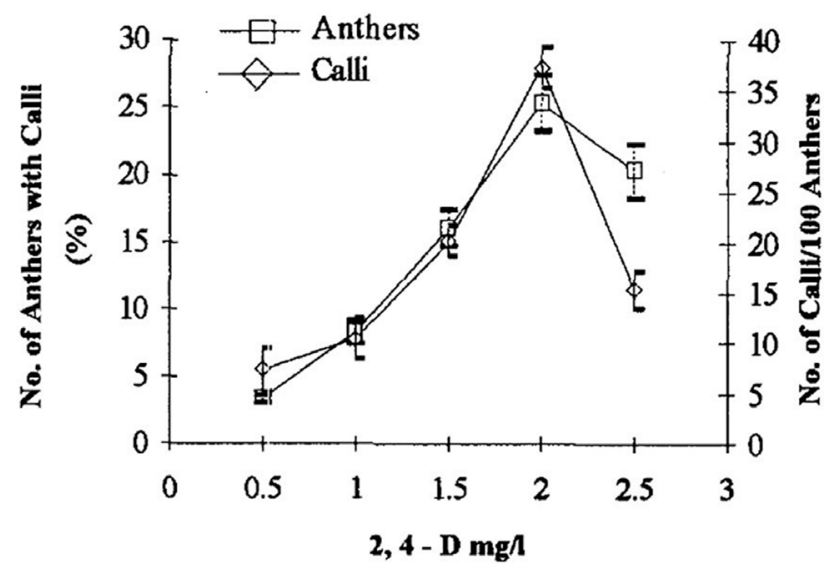

FIG URE 1 Adapted from Kumaravadivel and Sree Rangasamy (1994) shows the effect of 2,4-D on sorghum callus induction at $30^{\circ} \mathrm{C}$ on day 25 in anther culture

$3.7 \%$ with the greenhouse grown anthers after incubation in darkness at $30 \pm 1{ }^{\circ} \mathrm{C}$, where a total of 12,000 anthers were incubated. Can et al. (1998) found MS medium modified with $2.5 \mathrm{mg} / \mathrm{L}$ kinetin and $3.0 \mathrm{mg} / \mathrm{L}$ IAA to be the most effective for regeneration resulting in $27 \%$ frequency. A total of 63 plantlets were regenerated from the 248 calli obtained, out of which 43 were green and 20 albinos (Can et al., 1998).

\section{6 | PLOIDY LEVEL DETERMINATION AND CHROMOSOME DUPLICATION}

According to Dunwell (2010) haploids can be distinguished from their diploid counterparts by their generally small appearance owing to their smaller cell size as cell volume in plants is directly proportional to their ploidy level. However, there are various methods through which the ploidy level can be confirmed. Cytological techniques and measurement of the DNA using flow cytometry are the direct methods of ploidy level determination while the use of guard cell and plastid dimensions comprise the indirect methods (Dunwell, 2010; Yuan et al., 2009). Methods utilizing DNA markers for ploidy determination have also been described (Diao et al., 2009).

In the sorghum anther culture induction work of Rose et al. (1986), the ploidy level of the albino regenerants was neither determined nor discussed. Wen et al. (1991) on the other hand examined root tips from microspore derived calli using the method described by Tang and Liang (1987). There were 10, 20 and 40 chromosomes counted from root-tip cells of the regenerated plants of 'Xin White' variety (Wen et al., 1991). They reasoned that occurrence of 20 chromosomes from anther culture indicated that calli may have originated from somatic cells rather than from microspores. However, they argued that regeneration of albino plantlets suggested haploid plants may have been regenerated and that a few of the albino plantlets could have been a result of spontaneous chromosome doubling. Chromosome doubling was not reported for this work.
Twelve haploid and 248 doubled haploid plants were reported to have been regenerated in the work of Kumaravadivel and Sree Rangasamy (1994) from the culture of anthers from hybrid variety CSH5 (2077A x C83541). Similar to the work of Wen et al. (1991), chromosome counting of root tip cells was the method employed to determine ploidy level (Kumaravadivel \& Sree Rangasamy, 1994). It was reported that all the haploids developed and 116 of the $2 n$ plants were sterile while the rest were fertile. Sterility in the $2 n$ plants was thought to have been brought about by sterility inducing (S) cytoplasm from one of the parents (2077A) of the hybrid (Kumaravadivel \& Sree Rangasamy, 1994). Spontaneous chromosome doubling was reported to have occurred in $95.3 \%$ of the regenerated haploids, and therefore Kumaravadivel and Sree Rangasamy (1994) deemed genome doubling procedures to be unnecessary. On conducting field experiments that compared the regenerants with the original and selfed hybrid, it was observed that both quantitative and qualitative traits' variances were non-significant within family groups of the regenerants indicating rapid attainment of homozygosity, but significantly different when compared to those of the hybrid (Kumaravadivel \& Sree Rangasamy, 1994). According to Kumaravadivel and Sree Rangasamy (1994), the field performance of the regenerants strongly suggested the gametophytic origin of the explant and indicated fixation of alleles as expected in doubled haploids. In their work, Can et al. (1998) observed 20 chromosomes $(2 n)$ in most of the regenerants and unstable chromosome numbers in the rest. Can et al. (1998) used the method described by Hinata (1990) and modified by Can and Yoshida (1997) in determining ploidy level by root tip cell chromosomes observation. They concluded that the diploid plants observed may have been a result of spontaneous chromosome doubling of haploids or due to culture of somatic cells (Can et al., 1998).

\section{7 | CONCLUSION}

This review reiterates the observation that a well-developed protocol for sorghum anther culture remains largely unavailable or unreproducible. Nevertheless, the findings of the works highlighted point of desire to have this goal realized and are certainly positive strides towards this end. Like in the rest of the major cereals that are depended on for food security especially by the most vulnerable global populations, quicker release of varieties that are high yielding, stress tolerant and of greater industrial significance would be of great value. Doubled haploid technology has been relied upon and utilized in realizing these varieties in these other major cereal crops, as research on components of the technology including pretreatment, culture media composition, regeneration, ploidy level determination and chromosome duplication is at an advanced level. This paper points out the gaps that exist in this endeavour for sorghum anther culture and recommends efforts towards producing a reproducible protocol for the components of the technology pointed out, with special highlights on challenges that may be expected in its utilization. 


\section{ACKNOWLEDGEMENT}

The authors are grateful to Stipendium Hungaricum Scholarship under whose support this work was undertaken.

\section{ORCID}

Paul Chege (iD https://orcid.org/0000-0002-1593-5568

János Pauk iD https://orcid.org/0000-0002-8909-0529

\section{REFERENCES}

Adhikari, U., Nejadhashemi, A. P., \& Woznicki, S. A. (2015). Climate change and eastern Africa: A review of impact on major crops. Food and Energy Security, 4(2), 110-132. https://doi.org/10.1002/fes3.61

Anami, S. E., Zhang, L.-M., Xia, Y., Zhang, Y.-M., Liu, Z.-Q., \& Jing, H.C. (2015). Sweet sorghum ideotypes: Genetic improvement of stress tolerance. Food and Energy Security, 4(1), 3-24. https://doi. org/10.1002/fes 3.54

Barkley, A., \& Chumley, F. G. (2012). A doubled haploid laboratory for Kansas wheat breeding: An economic analysis of biotechnology adoption. International Food and Agribusiness Management Review, 15, 99-119.

Bhojwani, S. S., \& Dantu, P. K. (2013). Androgenesis. In Plant tissue culture: An introductory text (pp. 93-111). Springerhttps://doi. org/10.1007/978-81-322-1026-9_8

Binarova, P., Straatman, K., Hause, B., Hause, G., \& van Lammeren, A. A. M. (1993). Nuclear DNA synthesis during the induction of embryogenesis in cultured microspores and pollen of Brassica napus L. Theoretical and Applied Genetics, 87(1-2), 9-16. https://doi. org/10.1007/bf00223736

Can, N. D., Nakamura, S., Haryanto, T. A. D., \& Yoshida, T. (1998). Effects of physiological status of parent plants and culture medium composition on the anther culture of sorghum. Plant Production Science, 1(3), 211-215. https://doi.org/10.1626/pps.1.211

Can, N. D., \& Yoshida, T. (1997). Cytological study in root tip cells in four cultivars of Sorghum bicolor. Journal of the Faculty of Agriculture Kyushu University, 42, 11-16.

Chang, M.-T., \& Coe, E. H. (2009). Doubled haploids. In A. L. Kriz \& B. A. Larkins (Eds.), Molecular genetic approaches to maize improvement, biotechnology in agriculture and forestry (Vol. 63, pp. 127-142). Berlin, Heidelberg: Springer.

Chege, P., Palágyi, A., Lantos, C., Kiss, E., \& Pauk, J. (2020). Improved culture media for embryogenic callus generation in sorghum [Sorghum bicolor (L.) Moench]. Phyton, 89(1), 111-119. https://doi. org/10.32604/phyton. 2020.07554

Chu, C. C., Wang, C. C., Sun, C. S., Chen, H., Yin, K. C. et al (1975). Establishment of an efficient medium for anther culture of rice through comparative experiments on the nitrogen sources. Scientia Sinica, 18, 659-668.

Chuang, C. C., Ouyang, T. W., Chia, H., Chou, S. M., \& Ching, C. K. (1978). A set of potato media for wheat anther culture. In: Proceedings of Symposium on Plant Tissue Culture 1978 (pp 51-56). Peking: Science Press.

Diao, W.-P., Jia, Y.-Y., Song, H., Zhang, X.-Q., Lou, Q.-F., \& Chen, J.-F. (2009). Efficient embryo induction in cucumber ovary culture and homozygous identification of the regenerants using SSR markers. Scientia Horticulturae, 119(3), 246-251. https://doi.org/10.1016/j. scienta.2008.08.016

Dunwell, J. M. (2010). Haploids in flowering plants: Origins and exploitation. Plant Biotechnology Journal, 8(4), 377-424. https://doi. org/10.1111/j.1467-7652.2009.00498.x

Hause, B., Hause, G., Pechan, P., \& van Lammeren, A. A. M. (1993). Cytoskeletal changes and induction of embryogenesis in microspore and pollen cultures of Brassica napus L. Cell Biology International, 17(2), 153-168. https://doi.org/10.1006/cbir.1993.1052
Hickey, L. T., N. Hafeez, A., Robinson, H., Jackson, S. A., Leal-Bertioli, S. C. M., Tester, M., ... Wulff, B. B. H. (2019). Breeding crops to feed 10 billion. Nature Biotechnology, 37(7), 744-754. https://doi.org/10.1038/ s41587-019-0152-9

Hinata, Y. (1990) Chromosome observation method. In Dept. Agron. Fac. Agric., Tohoku Univ. (Ed.), Guide to experiments in agricultural sciences (pp. 31-33). Tokyo: Soft Science Publications.

Hoekstra, S., van Bergen, S., van Brouwershaven, I., Schilperoort, R., \& Wang, M. (1997). Androgenesis in Hordeum vulgare L.: Effects of mannitol, calcium and abscisic acid on anther pretreatment. Plant Science, 126(2), 211-218. https://doi.org/10.1016/s0168-9452(97)00096-4

Hu, T., \& Kasha, K. J. (1999). A cytological study of pretreatments used to improve isolated microspore cultures of wheat (Triticum aestivum L.) cv. Chris. Genome, 42(3), 432-441. https://doi.org/10.1139/ gen-42-3-432

Huang, B., \& Sunderland, N. (1982). Temperature-stress pretreatment in barley anther culture. Annals of Botany, 49(1), 77-88. https://doi. org/10.1093/oxfordjournals.aob.a086232

Hussain, T., \& Franks, C. (2019). Discovery of sorghum haploid induction system. In Z. Y. Zhao \& J. Dahlberg (Eds.), Sorghum, Methods in molecular biology (Vol. 1931, pp. 49-59). New York, NY: Humana Press. https://doi.org/10.1007/978-1-4939-9039-9_4

Indrianto, A., Heberle-Bors, E., \& Touraev, A. (1999). Assessment of various stresses and carbohydrates for their effect on the induction of embryogenesis in isolated wheat microspores. Plant Science, 143(1), 71-79. https://doi.org/10.1016/s0168-9452(99)00022-9

Jacquard, C., Wojnarowiez, G., \& Clément, C. (2003). Anther culture in barley. In M. Maluszynski, K. J. Kasha, B. P. Forster, \& I. Szarejko (Eds.), Doubled haploid production in crop plants(pp. 21-27). Dordrecht: Springer. https://doi.org/10.1007/978-94-017-1293-4_4

Kasha, K. J., Hu, T. C., Oro, R., Simion, E., \& Shim, Y. S. (2001). Nuclear fusion leads to chromosome doubling during mannitol pretreatment of barley (Hordeum vulgare L.) microspores. Journal of Experimental Botany, 52(359), 1227-1238. https://doi.org/10.1093/ $\mathrm{jxb} / 52.359 .1227$

Kasha, K. J., Simion, E., Oro, R., Yao, Q. A., Hu, T. C., \& Carlson, A. R. (2002). An improved in vitro technique for isolated microspore culture of barley. In M. Maluszynski \& K. J. Kasha (Eds.), Mutations, in vitro and molecular techniques for environmentally sustainable crop improvement (pp. 45-54). Dordrecht: Springer. https://doi. org/10.1007/978-94-015-9996-2_5

Keller, E. R. J, \& Korzun, L. (1996). Ovary and ovule culture for haploid production. In S. M. Jain, S. K. Sopory, \& R. E Veilleux (Eds.), In vitro haploid production in higher plants, Current plant science and biotechnology in agriculture (Vol. 23, pp. 217-235). Dordrecht: Springer. https://doi.org/10.1007/978-94-017-1860-8_13

Kiranmayee, K. N. S. U., Kishor, P. B. K., Hash, C. T., \& Deshpande, S. P. (2015). Evaluation of QTLs for shoot fly (Atherigona soccata) resistance component traits of seedling leaf blade glossiness and trichome density on sorghum (Sorghum bicolor) chromosome SBI-10L. Tropical Plant Biology, 9(1), 12-28. https://doi.org/10.1007/s1204 2-015-9157-9

Ko, W. H., Su, C. C., Chen, C. L., \& Chao, C. P. (2008). Control of lethal browning of tissue culture plantlets of Cavendish banana cv. Formosana with ascorbic acid. Plant Cell, Tissue and Organ Culture (PCTOC), 96(2), 137-141. https://doi.org/10.1007/s1124 0-008-9469-7

Kumaravadivel, N., \& Sree Rangasamy, S. R. (1994). Plant regeneration from sorghum anther cultures and field evaluation of progeny. Plant Cell Reports, 13(5), https://doi.org/10.1007/bf00233321

Liang, G. H., Gu, X., Yue, G., Shi, Z. S., \& Kofoid, K. D. (1997). Haploidy in sorghum. In S. M. Jain, S. K. Sopory, \& R. E. Veilleux (Eds.), In vitro haploid production in higher plants, Current plant science and biotechnology in agriculture (Vol. 26, pp. 149-161). Dordrecht: Springer. https:// doi.org/10.1007/978-94-017-1862-2_7 
Liu, G., Gilding, E. K., \& Godwin, I. D. (2015). A robust tissue culture system for sorghum [Sorghum bicolor (L.) Moench]. South African Journal of Botany, 98, 157-160. https://doi.org/10.1016/j.sajb.2015.03.179

Liu, W., Zheng, M., \& Konzak, C. (2002a). Improving green plant production via isolated microspore culture in bread wheat (Triticum aestivum L.). Plant Cell Reports, 20(9), 821-824. https://doi.org/10.1007/ s00299-001-0408-x

Liu, W., Zheng, M. Y., Polle, E. A., \& Konzak, C. F. (2002b). Highly efficient doubled-haploid production in wheat (Triticum eastivum L.) via induced microspore Embryogenesis. Crop Science, 42(3), 686-692. doi:10.2135/cropsci2002.6860.

Masteller, V. J., \& Holden, D. J. (1970). The growth of and organ formation from callus tissue of sorghum. Plant Physiology, 45(3), 362-364. https://doi.org/10.1104/pp.45.3.362

Mbuvi, D. A., Masiga, C. W., Kuria, E., Masanga, J., Wamalwa, M., Mohamed, A., ... \& Runo, S. (2017). Novel sources of witchweed (Striga) resistance from wild sorghum accessions. Frontiers in Plant Science, 8, 116. https://doi.org/10.3389/fpls.2017.00116..

Mindaye, T. T., Mace, E. S., Godwin, I. D., \& Jordan, D. R. (2016). Heterosis in locally adapted sorghum genotypes and potential of hybrids for increased productivity in contrasting environments in Ethiopia. The Crop Journal, 4(6), 479-489. https://doi.org/10.1016/j. cj.2016.06.020

Mundia, C. W., Secchi, S., Akamani, K., \& Wang, G. (2019). A Regional comparison of factors affecting global sorghum production: The case of North America. Asia and Africa's Sahel. Sustainability, 11(7), 2135. https://doi.org/10.3390/su11072135

Murashige, T., \& Skoog, F. (1962). A revised medium for rapid growth and bioassays with tobacco tissue cultures. Physiologia Plantarum, 15(3), 473-497. https://doi.org/10.1111/j.1399-3054.1962.tb08052.x

Nageli, M., Schmid, J. E., Stamp, P., \& Buster, B. (1999). Improved formation of regenerable callus in isolated microspore culture of maize: Impact of carbohydrates, plating density and time of transfer. Plant Cell Reports, 19(2), 177-184. https://doi.org/10.1007/s0029 90050730

Ndjeunga, J., Mausch, K., \& Simtowe, F. (2015). Assessing the effectiveness of agricultural R\&D for groundnut, pearl millet, pigeonpea and sorghum in West and Central Africa and East and Southern Africa. In T. S. Walker \& J. Alwang (Eds.), Crop improvement, adoption, and impact of improved varieties in food crops in Sub-Saharan Africa (pp. 123-147). Niger: ICRISAT. https://doi.org/10.1079/9781780644 011.0123

Pontieri, P., Mamone, G., De Caro, S., Tuinstra, M. R., Roemer, E., Okot, J., ... Del Giudice, L. (2013). Sorghum, a Healthy and Gluten-free Food for Celiac Patients As Demonstrated by Genome, Biochemical, and Immunochemical Analyses. Journal of Agricultural and Food Chemistry, 61(10), 2565-2571. https://doi.org/10.1021/jf304882k

Portemer, V., Renne, C., Guillebaux, A., \& Mercier, R. (2015). Large genetic screens for gynogenesis and androgenesis haploid inducers in Arabidopsis thaliana failed to identify mutants. Frontiers in Plant Science, 6, 147. https://doi.org/10.3389/fpls.2015.00147

Ringo, J. H., Onkware, A., Mgonja, M. A., Deshpande, S., Rathore, A., Mneney, E. E., \& Gudu, S. (2015). Heterosis for yield and its components in sorghum (Sorghum bicolor L. Moench) hybrids in dry lands and sub-humid environments of East Africa. Australian Journal of Crop Science, 9, 9-13.

Rizal, G., Karki, S., Alcasid, M., Montecillo, F., Acebron, K., Larazo, N., ... Quick, W. P. (2014). Shortening the breeding cycle of sorghum, a model crop for research. Crop Science, 54(2), 520-529. https://doi. org/10.2135/cropsci2013.07.0471

Rose, J. B., Dunwell, J. M., \& Sunderland, N. (1986). Anther culture of Sorghum bicolor (L.) Moench. Plant Cell, Tissue and Organ Culture, 6(1), 15-22. https://doi.org/10.1007/BF00037754

Srinivasa-Rao, P., Reddy, B. V. S., Nagaraj, N., \& Upadhyaya, H. D. (2014). Sorghum production for diversified uses, genetics, genomics and breeding of sorghum. In Y. -H. Wang, H. D. Upadhyaya, \& C. Kole (Eds.), Genetics, genomics and breeding of sorghum, Series on genetics, genomics and breeding of crop plants, (1st ed., pp. 1-27). Boca Raton: CRC Press. https://doi.org/10.1201/b17153

Tang, H., \& Liang, G. H. (1987). An improved technique for cytological observations and occurrence of polysomaticism in sorghum root tips. Journal of Heredity, 78(1), 51-53. https://doi.org/10.1093/oxfordjour nals.jhered.a110308

Tari, I., Laskay, G., Takács, Z., \& Poór, P. (2012). Response of sorghum to abiotic stresses: A review. Journal of Agronomy and Crop Science, 199(4), 264-274. https://doi.org/10.1111/jac.12017

Teingtham, K. (2017). Is doubled haploid production in sorghum impossible? KMUTNB International Journal of Applied Science and Technology, 10(4), 247-256. https://doi.org/10.14416/j.ijast.2017.11.001

Touraev, A., Pfosser, M., \& Heberle-Bors, E. (2001). The microspore: A haploid multipurpose cell. In J. Callow (Ed.), Advances in botanical research (Vol. 35, pp. 53-109). London, United Kingdom: Academic Press.https://doi.org/10.1016/s0065-2296(01)35004-8

Touraev, A., Pfosser, M., Vicente, O., \& Heberle-Bors, E. (1996). Stress as the major signal controlling the developmental fate of tobacco microspores: towards a unified model of induction of microspore/pollen embryogenesis. Planta, 200(1), 144-152. https://doi.org/10.1007/ BF00196662

Touraev, A., Vicente, O., \& Heberle-Bors, E. (1997). Initiation of microspore embryogenesis by stress. Trends in Plant Science, 2(8), 297-302. https://doi.org/10.1016/s1360-1385(97)89951-7

The Odum Institute. (2017). Time series plot and the USDA feed grains database (1876-2015): U.S. corn production. SAGE Publications, Ltd. https://doi.org/10.4135/9781473995772

Wędzony, M., Forster, B. P., Żur, I., Golemiec, E., Szechyńska-Hebda, M. et al (2009). Progress in doubled haploid technology in higher plants. In A. Touraev, B. P. Forster, \& S. M. Jain (Eds.), Advances in haploid production in higher plants (pp. 1-33). Dordrecht, Netherlands: Springer. https://doi.org/10.1007/978-1-4020-8854-4_1

Wen, F. S., Sorensen, E. L., Barnett, F. L., \& Liang, G. H. (1991). Callus induction and plant regeneration from anther and inflorescence culture of Sorghum. Euphytica, 52(3), 177-181. https://doi.org/10.1007/ bf00029394

Wernicke, W., Potrykus, I., \& Thomas, E. (1982). Morphogenesis from cultured leaf tissue of Sorghum bicolor? The Morphogenetic Pathways. Protoplasma, 111(1), 53-62. https://doi.org/10.1007/bf01287646

Yuan, S., Liu, Y., Fang, Z., Yang, L., Zhuang, M., Zhang, Y., \& Sun, P. (2009). Study on the relationship between the ploidy level of microspore-derived plants and the number of chloroplast in stomatal guard cells in Brassica oleracea. Agricultural Sciences in China, 8(8), 939-946. https://doi.org/10.1016/s1671-2927(08)60298-9

Žárský, V., Garrido, D., Říhová, L., Tupý, J., Vicente, O., \& HeberleBors, E. (1992). Derepression of the cell cycle by starvation is involved in the induction of tobacco pollen embryogenesis. Sexual Plant Reproduction, 5(3), 189-194. https://doi.org/10.1007/bf001 89810

Žárský, V., Garrido, D., Říhová, L., Tupý, J., Vicente, O., Schoffl, F., \& Heberle-Bors, E. (1995). The expression of a small heat shock gene is activated during induction of tobacco pollen embryogenesis by starvation. Plant, Cell and Environment, 18(2), 139-147. https://doi. org/10.1111/j.1365-3040.1995.tb00347.x

Zhao, J.-P., Simmonds, D. H., \& Newcomb, W. (1996). Induction of embryogenesis with colchicine instead of heat in microspores of Brassica napus L. cv. Topas. Planta, 198(3), 433-439. https://doi.org/10.1007/ bf00620060

Zhao, Z., Cai, T., Tagliani, L., Miller, M., Wang, N. et al (2000). Agrobacterium-mediated sorghum transformation. Plant Molecular Biology, 44, 789.

Zheng, M. Y., Weng, Y., Sahibzada, R., \& Konzak, C. F. (2003). Isolated microspore culture in maize (Zea mays L.). In M. Maluszynski, 
K. J. Kasha, B. P Forster, \& I Szarejko (Eds.), Production of doubled-haploids via induced androgenesis, Doubled haploid production in crop plants (pp. 95-102). Dordrecht: Springer. https://doi. org/10.1007/978-94-017-1293-4_15
How to cite this article: Chege P, Lantos C, Pauk J. Retrospect on in vitro androgenesis of sorghum (Sorghum bicolor). Plant Breed. 2020;00:1-9. https://doi.org/10.1111/pbr.12843 